\title{
Impact of a global leader on pharmaceutical practice and policy around the world
}

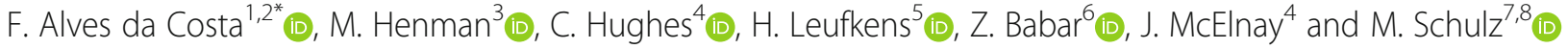

\begin{abstract}
This commentary describes the contributions of a Dutch pharmacist who contributed in a unique manner to the development of community pharmacy practice in Europe, to the evolution of practice-based research and to its publication. With an interest in pharmaceutical care and in clinical pharmacy, Dr. van Mil changed practice and policy in Europe over the last decades in a very visible way, here documented through a summary of some of his main written contributions. We write this to honour his memory and contribute to the preservation of his legacy.
\end{abstract}

Keywords: Pharmaceutical care, Medication review, Clinical pharmacy, Europe

The first reference to pharmaceutical care dates to 1975 [1], and successive definitions and operationalisation of the term have continued across the world. However, many of these were largely descriptive or pilot studies, with little impact on practice or simply refinements of terminology which did not transfer into policy which is essential to lead to changes in the scope of practice of pharmacists working in various health care settings.

A pragmatic approach, a strong character and a drive to make the world a better place are some of the phrases that could be used to describe Dr. Foppe van Mil, who died on 18 July 2020 . This commentary summarises the most relevant achievements of a unique career that has had an impact on the practice, research or policy relating to pharmacy across the world, either working on his own or, more often, collaboratively with academic or practice-based teams. Table 1 summarises many of the projects with which Dr. van Mil was associated alongside some key publications that influenced practitioners, researchers and policy-makers, including his $\mathrm{PhD}$ thesis

\footnotetext{
* Correspondence: alvesdacosta.f@gmail.com

${ }^{1}$ Faculty of Pharmacy, University of Lisbon, Lisbon, Portugal

${ }^{2}$ University Institute Egas Moniz, Lisbon, Portugal

Full list of author information is available at the end of the article
}

which was a landmark for pharmacy practice in the Netherlands, expanding its impact to many other countries [2].

He was involved in the first two pharmaceutical care research projects in Europe; in the Asthma Intervention Project (TOM), he was a postgraduate student, and in the Care of the Elderly study (OMA), he was a leading member of the research team $[3,6]$. Both projects took a holistic approach to patient care and involved international collaboration, two aspects that were characteristic of Foppe's conception of research. The major influence on Foppe's research involvement, and on his influence on his colleagues, was his experience and expertise as a community pharmacist; this made him very practical but also very demanding, because for him, research was about, and for, the benefit of patients. His reputation reached all countries, and even countries recognised as having an advanced practice, including the UK, benefited from visiting his practice in the Netherlands [21].

Foppe had a very visible contribution to the dissemination of research and pharmacy practice, by his various attributes and activities. He was an educator, but a practical one, who once committed, would work tirelessly to 
Table 1 Summary of practice, research projects and recognitions that have impacted pharmaceutical care practice or policy

\begin{tabular}{ll}
\hline Title & Brief description \\
\hline "Therapeutic & TOM is a model for increasing \\
Outcomes & pharmacists' role in primary \\
Monitoring" & health care, based on a continuous \\
(TOM) project & quality improvement system applied \\
& to PhC to detect, prevent and resolve \\
& DRPs in asthma patients. This project \\
& was conducted as a controlled \\
& intervention study (grouped at the \\
& pharmacy level) and various outcomes \\
& were measured to assess the impact of \\
& the intervention (e.g. HRQoL, PEFR, \\
& satisfaction).
\end{tabular}

\begin{abstract}
Elderly Study of the effect of PhC in the elderly Medication (>65 years) using 4 or more different Analysis (OMA drugs and living independently. project) Designed as a controlled study with randomisation at the pharmacy level and involved 1290 intervention patients (selected in 104 pharmacies) and 1164 controls (selected from 86 pharmacies). Outcomes measured included HRQoL, patient satisfaction and knowledge, provider satisfaction (GP and pharmacist), drug use (including adherence) and use of health services.
\end{abstract}

Review article Discusses the concept of PhC care from a European perspective and clarifies the status of PhC research and implementation. It discusses if PhC can be part of the practice of pharmacy.

Review article Describes European developments in the implementation of and research into $\mathrm{PhC}$, focusing on the community pharmacy.

Opinion paper Establishes the need and the rationale for using a classification of DRPs to avoid negative consequences for patients.

Terminology This sequence of publications establishes papers the foundations for understanding concepts of PhC, clinical pharmacy and medication review, highlighting the boundaries and similarities between concepts, while reflecting the evolution in practices.

Research paper Development of a PCNE-DRP classification.

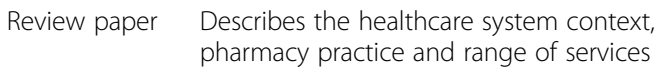
pharmacy practice and range of services
offered in pharmacies in the Netherlands.

Review paper Describes the healthcare system context, Peru (South America) pharmacy practice and range of services offered in pharmacy in Peru.

Research paper Describes the healthcare system context, Europe pharmacy practice and range of services offered in pharmacy in Europe. Netherlands
Europe

Europe

Germany

Worldwide, with a special focus in Europe

World

The Netherlands

\begin{tabular}{|c|c|c|}
\hline Countries involved & Impact & References \\
\hline $\begin{array}{l}\text { Austria, Belgium, Canada, } \\
\text { Denmark, Florida (USA), } \\
\text { Germany, Iceland, Northern } \\
\text { Ireland, The Netherlands }\end{array}$ & $\begin{array}{l}\text { These controlled intervention studies } \\
\text { had a huge impact on implementing } \\
\text { pharmacy practice research at the } \\
\text { university level in many countries. } \\
\text { Furthermore, results achieved led to } \\
\text { recognise pharmacist in DMPs and } \\
\text { clinical practice guidelines. Today, there } \\
\text { are specific programmes, often } \\
\text { remunerated, for pharmacists to support } \\
\text { inhaled medication used, namely in } \\
\text { Belgium, in Denmark, to name a few. }\end{array}$ & {$[2-5]$} \\
\hline
\end{tabular}

Sweden, Portugal, Northern This was a landmark study as it was the Ireland, Denmark, Germany, first multicentred study in European Republic of Ireland, The community pharmacies. It was influential in the field of pharmacy practice research.

It suggests changes in the pharmacy curriculum so that pharmacists can acquire new knowledge and skills. It encourages countries to standardise procedures adopted to guarantee every patient receives $\mathrm{PhC}$.

Paper by invitation of the Harvard Health Policy Review (USA).

Motivated the adoption of such classifications in pharmacy practice in both primary and secondary care.

These definitions are used by academics and researchers worldwide to support teaching and educational activities.

Currently being used in Belgium, China,

Germany, Ghana, Norway, Poland, Portugal, Serbia, Slovenia, Spain, Sweden, and Taiwan.

Used widely as reference to frame various research or practice based studies undertaken in this counrty

Used widely as reference to frame various research or practice based studies undertaken in this counrty

Provides a framework for countries to benchmark themselves against each other. 
Table 1 Summary of practice, research projects and recognitions that have impacted pharmaceutical care practice or policy (Continued)

\begin{tabular}{|c|c|c|c|c|}
\hline Title & Brief description & Countries involved & Impact & References \\
\hline Research paper & $\begin{array}{l}\text { Describes the medication review } \\
\text { practices in Europe, implementation and } \\
\text { remuneration models associated. }\end{array}$ & Europe & $\begin{array}{l}\text { Provides an assessment of the } \\
\text { implementation of medication review in } \\
\text { Europe, enabling benchmark and analysis } \\
\text { of the strong points of some of the } \\
\text { countries described in more detail. }\end{array}$ & {$[20]$} \\
\hline $\begin{array}{l}\text { Editor-in-Chief } \\
\text { of the Int J Clin } \\
\text { Pharm }\end{array}$ & $\begin{array}{l}\text { Published high-quality manuscripts that } \\
\text { enhanced the visibility of pharmaceutical } \\
\text { care and clinical pharmacy in various } \\
\text { countries of the world. }\end{array}$ & Worldwide & $\begin{array}{l}\text { These publications have } \\
\text { provided evidence-based practice } \\
\text { to motivate policy changes in many } \\
\text { countries, including in some cases } \\
\text { changes in the scope of practice or } \\
\text { remuneration models for pharmacy. }\end{array}$ & $\begin{array}{l}\text { Pharmacy } \\
\text { practice } \\
\text { commentary on } \\
\text { social media ( } 22 \\
\text { July 2020) }\end{array}$ \\
\hline
\end{tabular}

deliver high quality. He was involved for many years in the Programme Committee for the Continuing Education Programme organised by the Community Pharmacy Section of the International Pharmaceutical Federation (FIP), through which annual sessions were held as presatellite meetings. These sessions aimed at the continuous professional development of pharmacists, particularly in the area of pharmaceutical care, and have led to the improvement of knowledge and practice skills of community pharmacists [22]. The aims, development and impact measurements of this programme were published subsequently [23]. FIP and the World Health Organization (WHO) collaborated to deliver a course on pharmaceutical care in Uruguay and other Latin American countries and chose Foppe to do this. He used a train-the-trainer model, in which theory-based sessions were followed by visits to the settings where the trainers practised to better understand their reality and adapt the learnings to their needs.

Two of the main vehicles for the advancement and dissemination of knowledge in the field of pharmaceutical care in Europe are the European Society of Clinical Pharmacy (ESCP) and the Pharmaceutical Care Network Europe (PCNE). As a member of ESCP, Foppe delivered workshops and lectures over many years and helped to promote research through his contributions to the Communication Committee. His unique contribution was cofounding the PCNE (in 1994), and he was truly its backbone; irrespective of the challenges, whether organisational, fiscal or philosophical, Foppe persevered and his belief in the value of PCNE and consequently sustained everyone in it. The definition of pharmaceutical care, the classification of drug-related problems and the conception of medication reviews all depended on Foppe's initiative, determination and implementation. In addition through national organisations, such as the "Förderinitiative Pharmazeutische Betreuung" (Foundation Pharmaceutical Care) in Germany and at national pharmacy conferences, for example, in Poland [24] and at special occasions such as the award ceremony of the Royal
Pharmaceutical Society of Great Britain, Foppe was an invited and valued contributor.

Foppe van Mil was an extraordinary person in the Dutch pharmacy practice space and beyond. Always vocal, always committed to innovation for the well-being of patients and public health. He was a very straightforward, yet unorthodox person, who combined in a very original and appealing manner practice and academic work, at the University of Groningen. His drive to make a difference, both in teaching and in research, was amazing and has always been well acknowledged. He was a recipient of the Innovation Prize of the Royal Dutch Association of Pharmacists (KNMP), a unique signature of excellence and leadership. This public recognition of innovative practice with visible benefits for patients contributed to further dissemination of the concept of pharmaceutical care and its implementation in practice there [2]. But many other institutions and organisations have publicly recognised him for his contribution leading to the advancements in research and practice. In Spain, during the first International Congress of Pharmaceutical Care (Atención Farmacéutica, San Sebastian 1999), he received together with Doug Hepler and Linda Strand (both from the USA) the Pharmaceutical Association of Gipuzkoa Award, as the judges considered these three individuals were, at that time, those with the most significant contributions to the advancement of pharmaceutical care internationally and whom, as such, stimulated the move to further the concept of pharmaceutical care in Spain, leading to its recognition and establishment in the law some years later.

In addition to Foppe's contribution to the dissemination of research and practice innovation to researchers and pharmacy practitioners through his lectures and workshops, he made a very significant contribution in knowledge translation through his efficient and effective editorship of the International Journal of Clinical Pharmacy (IJCP). Throughout his time as editor-in-chief, he encouraged students and practitioners to publish their work. This journal, originally named Pharm. Weekblad 
- Scientific Edition, which was a scientific publication, became known first, as Pharmacy World \& Science (PWS), and then in 2010, was renamed to IJCP. His work in this regard was transformative and leads to the remoulding of the journal into one with a substantial international impact.

Foppe was a great supporter of evidence-informed pharmaceutical policy at a global level. In 2009, he helped publish a key editorial in "Pharmacy World and Science" regarding the starting of the journal "Southern Med Review", later renamed as "Journal of Pharmaceutical Policy and Practice", as he believed there was a paucity of journals focused on pharmaceutical policy, which were needed to complement the more practice-based ones [25].

At a later stage of his career, he edited a book aimed at helping practitioners worldwide to implement pharmaceutical care. This was indeed the main aim of his life, to transform standard pharmacy practice, or usual care as it is often called in randomised controlled trials, into pharmaceutical care and make this advanced way of constantly optimising medication usual practice. In this book, he gathered more than 40 worldwide reputed authors and covered all aspects believed to be essential for practice implementation, from disease-specific to health care setting-specific, to country-specific and of course not forgetting about university education and continuous professional development [26].

He will be greatly missed by all his friends, colleagues and followers throughout the world.

\begin{abstract}
Abbreviations
DMP: Disease management programme; DRPs: Drug-related problems; ESCP: European Society of Clinical Pharmacy; GP: General practitioner; FIP: International Pharmaceutical Federation; HRQoL: Health-related quality of life; Int J Clin Pharm: International Journal of Clinical Pharmacy; KNMP: Koninklijke Nederlandse Maatschappij ter bevordering der Pharmacie; PCNE: Pharmaceutical Care Network Europe; PEFR: Peak expiratory flow rate; PhC: Pharmaceutical care; WHO: World Health Organization
\end{abstract}

\section{Authors' contributions}

FAC drafted the original manuscript. All authors contributed to its content by providing additional information. MH proof read the manuscript. All authors read and approved the final manuscript.

\section{Funding}

None.

\section{Availability of data and materials}

Not applicable

\section{Ethics approval and consent to participate}

Not applicable

\section{Consent for publication}

All authors approved the manuscript.

\section{Competing interests}

ZUDB is the Editor in Chief of the Journal of Pharmaceutical Policy and Practice.

FAC is Associate Editor of the International Journal of Clinical Pharmacy.
$\mathrm{HL}$ is the Regional Editor for Europe of Pharmacoepidemiology and Drug Safety.

The other authors declare no competing interests.

\section{Author details}

${ }^{1}$ Faculty of Pharmacy, University of Lisbon, Lisbon, Portugal. ${ }^{2}$ University Institute Egas Moniz, Lisbon, Portugal. ${ }^{3}$ School of Pharmacy and

Pharmaceutical Sciences, University of Dublin Trinity College, Dublin, Ireland.

${ }^{4}$ Clinical and Practice Research Group, School of Pharmacy, Medical Biology

Centre, Queen's University Belfast, Belfast, UK. ${ }^{5}$ Division of

Pharmacoepidemiology and Clinical Pharmacology, Utrecht Institute for Pharmaceutical Sciences, Utrecht University, Utrecht, the Netherlands. ${ }^{6}$ Pharmaceutical Policy and Practice Research Centre at the Department of Pharmacy, University of Huddersfield, Queensgate, Huddersfield HD1 3DH, UK. ${ }^{7}$ Department of Medicine, ABDA - Federal Union of German Associations of Pharmacists, Berlin, Germany. ${ }^{8}$ Institute of Pharmacy, Freie Universität Berlin, Berlin, Germany.

Published online: 21 August 2020

\section{References}

1. Mikael RL, Brown TR, Lazarus HL, Vinson MC. Quality of pharmaceutical care in hospitals. Am J Hosp Pharm. 1975;32:567-74.

2. van Mil JWF. Pharmaceutical care, the future of pharmacy: theory, research, and practice [thesis]. The Netherlands: University of Groningen; 2000.

3. van Mil JWF, Tromp TFJ. Pharmaceutical care in the Netherlands. History, definition and projects. Pharm World Sci. 1996;18:237-40.

4. Herborg H, Søndergaard B, Frøkjær B, Fonnesbæk L, Jörgensen T, Hepler CD, Grainger-Rousseau T-J, Ersbø\|l BK. Improving drug therapy for patients with asthma - Part 1: Patient outcomes. J Am Pharm Assoc. 2001;41(4):539-50.

5. Schulz, M., Verheyen, F., Mühlig, S., Müller, J.M., Mühlbauer, K., KnopSchneickert, E., Petermann, F. and Bergmann, K.-C. Pharmaceutical care services for asthma patients. A controlled intervention study. J Clin Pharmacol. 41, 2001, Vol. 6, pp. 668-676.

6. Bernsten C, Björkman I, Caramona M, Crealey G, Frokjaer B, Grundberger E, Gustafsson T, Henman M, Herborg H, Hughes CM, McElnay JC, Magner M, Van Mil F, Schaeffer M, Silva S, Sondergaard B, Sturgess I, Tromp D, Vivero L. Improving the well-being of elderly patients via community pharmacybased provision of pharmaceutical care: a multicentre study in seven European countries. Drugs Aging. 2001;18(1):63-77.

7. van Mil JWF, Schulz M, Tromp TFJ. (Dick). Pharmaceutical care, European developments in concepts, implementation, teaching, and research: a review. Pharm World Sci. 2004;26:303-11.

8. van Mil JWF, Schulz M. A review of pharmaceutical care in community pharmacy in Europe. Harvard Health Policy Review. 2006;7(1):155-68.

9. van Mil F, Schaefer M, Verheyen F, Schulz M. Arzneimittelbezogene Probleme in der öffentlichen Apotheke. Pharm Ztg. 2001;16(146):1308-14.

10. Franklin BD, van Mil JW. Defining clinical pharmacy and pharmaceutical care. Pharm World Sci. 2005;27(3):137.

11. van Mil JW, Fernandez-Llimos F. What is 'pharmaceutical care' in 2013? Int J Clin Pharm. 2013;35(1):1-2.

12. Allemann SS, van Mil JW, Botermann L, Berger K, Griese N, Hersberger KE. Pharmaceutical care: the PCNE definition 2013. Int J Clin Pharm. 2014;36(3): 544-55.

13. Griese-Mammen N, Hersberger KE, Messerli M, et al. PCNE definition of medication review: reaching agreement. Int J Clin Pharm. 2018:40(5):1199-208.

14. van Mil JW, Westerlund LO, Hersberger KE, Schaefer MA. Drug-related problem classification systems. Ann Pharmacother. 2004;38(5):859-67.

15. Eichenberger PM, Lampert ML, Kahmann IV, van Mil JW, Hersberger KE. Classification of drug-related problems with new prescriptions using a modified PCNE classification system. Pharm World Sci. 2010;32(3):362-72.

16. van Mil JF, Westerlund T, Brown L, Chen TF, Henman M, Hersberger K, McElnay J, Schulz M. Medical care and drug-related problems: do doctors and pharmacists speak the same language? Int J Clin Pharm. 2016;38:2.

17. van Mil JW. Pharmaceutical Care in community pharmacy: practice and research in the Netherlands. Ann Pharmacother. 2005;39(10):1720-5.

18. Alvarez-Risco A, van Mil JW. Pharmaceutical care in community pharmacies: practice and research in Peru. Ann Pharmacother. 2007;41(12):2032-7.

19. Martins SF, van Mil JW, da Costa FA. The organizational framework of community pharmacies in Europe. Int J Clin Pharm. 2015;37(5):896-905. 
20. Imfeld-Isenegger TL, Soares IB, Makovec UN, Horvat N, Kos M, van Mil F, et al. Community pharmacist-led medication review procedures across Europe: characterization, implementation and remuneration. Res Soc Adm Pharm. 2020;16(8):1057-66.

21. Mason P. Pharmaceutical care: doing it the Dutch way. Pharm J. 2000; 264(7099):854-5.

22. Van Mil JWF, Hepler CD. Drug therapy in the elderly: problems and solutions II: depression and hypertension. In: Hepler CD, editor. Introduction to Pharmaceutical Carefor the elderly. Lisbon: FIP; 1994

23. van Mil J W F, Frokjaer B, Tromp Th F J. Changing a profession, influencing community pharmacy. Pharm World Sci. 26, 2004, Vol. 3, pp. 129-132.

24. Van Mil, F., \& Tromp, D. Opieka farmaceutyczna: Jak wprowadzic ją w życie? armacja Polska. 57, 2001, Vol. 23, pp. 1063-1067.

25. Babar Z, Beswick T. Southern Med Review: a new forum to publish "Local Pharmaceutical Policy in a Global Context". Pharm World Sci. 2009;31:143-4.

26. Alves da Costa, F., van Mil, J., Alvarez Risco, A. The pharmacist guide to implementing pharmaceutical care. Springer, 2019.

\section{Publisher's Note}

Springer Nature remains neutral with regard to jurisdictional claims in published maps and institutional affiliations.

Ready to submit your research? Choose BMC and benefit from:

- fast, convenient online submission

- thorough peer review by experienced researchers in your field

- rapid publication on acceptance

- support for research data, including large and complex data types

- gold Open Access which fosters wider collaboration and increased citations

- maximum visibility for your research: over $100 \mathrm{M}$ website views per year

At BMC, research is always in progress.

Learn more biomedcentral.com/submissions 